\title{
PENDAMPINGAN PENGUATAN PENDIDIKAN KARAKTER MELALUI PERMAINAN EDUKATIF DI PAUD MEKAR KECAMATAN NOYAN
}

\author{
Yulita Dewi Purmintasari ${ }^{1}$, Sahid Hidayat ${ }^{2}$, Yuver Kusnoto ${ }^{3}$ \\ ${ }^{1,2,3}$ Program Studi pendidikan Sejarah, Fakultas Ilmu Pendidikan dan Pengetahuan Sosial \\ IKIP PGRI Pontianak, Jalan Ampera No. 88 \\ 1e-mail: yuverkusnoto@ikippgriptk.ac.id
}

\begin{abstract}
Abstrak
Tujuan kegiatan pengabdian untuk menguatkan pedidikan karakter melalui permainan edukatif di PAUD Mekar Kecamatan Noyan. Langkah-langkah yang dilakukan oleh tim dalam rangka melaksakan kegiatan ini adalah sebagai berikut: (1) Survey, (2) Pemantapan dan penentuan lokasi dan sasaran, (3) Pembelian bahan permainan edukasi, (4) pelaksanaan pendampingan penguatan pendidikan karakter melalui permainan edukatif. Penguatan pendidikan karakter untuk anak PAUD dapat dilakukan dengan menggunakan permainan edukasi. Ketika permainan itu digunakan dengan tepat dan dalam pengawasan guru maupun orang tua dapat ditanamkan nilai-nilai pendidikan karakter religius, jujur, toleransi, disiplin, kerja keras, kreatif, mandiri, demokratis, rasa ingin tahu, semangat kebangsaan, cinta tanah air, menghargai prestasi, bersahabat/komunikatif, cinta damai, gemar membaca dan peduli lingkungan.
\end{abstract}

Kata Kunci: Pendidikan Karakter, Permainan edukatif, PAUD

\begin{abstract}
The purpose of the service activities is to strengthen character education through educative games at PAUD Mekar Subdistrict Noyan. The steps taken by the team to carry out these activities are as follows: (1) Survey, (2) Establishment and determination of locations and targets, (3) Purchase of educational game materials, (4) Implementation of character education strengthening assistance through educational games. Strengthening character education for PAUD children can be done using educational games. When the game is used appropriately and in the supervision of the teacher and parents can be embedded the values of religious character education, honest, tolerance, discipline, hard work, creative, independent, democratic, curiosity, national spirit, love for the country, respect for achievement, friendly/communicative, love peace, love to read and care for the environment.
\end{abstract}

Keywords: Character education, educational games, PAUD

\section{PENDAHULUAN}

Mitra dalam program pengabdian kepada masyarakat ini yaitu PAUD Mekar Desa Noyan Kecamatan Noyan Kabupaten Sanggau. Desa Noyan merupakan salah satu desa yang tergolong wilayah terpencil di Kabupaten Sanggau, yang juga berdekatan dengan perbatasan, sebelum tahun 2010 masuk dalam ring tiga perbatasan. Lama perjalanan dari Pontianak menuju kecamatan Noyan menggunakan kendaraan mobil lebih kurang selama lima jam, dengan jarak lebih 
kurang $247 \mathrm{~km}$. Dari perbatasan Entikong menuju Balai Karangan harus menempuh perjalanan lebih kurang dua jam.

Untuk menuju kecamatan Noyan bisa menggunakan dua jalur yaitu jalur Balai Karangan dan jalur Kembayan akses transportasi dari kecamatan Sekayam maupun dari Kembayan akan lebih efektif menggunakan kendaraan pribadi. Apabila mengunakan kendaraan umum atau angkutan umum sangat terbatas, satusatunya kendaraan umum menggunakan mobil truk mini yang di modifikasi seperti angkutan penumpang dari Balai Karangan Kecamatan Sekayam.

Kondisi lokasi yang jauh dari keramaian tidak menyurutkan semangat belajar warganya. Orang tua antusias untuk menyekolahkan anaknya agar mendapatkan pendidikan yang terbaik, agar mampu juga bersosialisasi dengan teman sebaya.

Kesadaran untuk belajar tersebut sejalan dengan Sagala (2006: 61) yang menyatakan pembelajaran adalah membelajarkan peserta didik menggunakan asas pendidikan maupun teori belajar yang merupakan penentu utama keberhasilan pendidikan. Menurut Suyadi (2010: 16) bahwa pembelajaran anak usia dini dilakukan melalui kegiatan bermain yang dipersiapkan oleh pendidik dengan menyiapkan materi (konten) dan proses belajar.

Anak usia dini adalah anak yang berada pada usia 0-8 tahun. Menurut Beichler dan Snowman (Yulianti, 2010: 7), anak usia dini adalah anak yang berusia antara 3-6 tahun. Sedangkan hakikat anak usia dini (Augusta, 2012) adalah individu yang unik dimana ia memiliki pola pertumbuhan dan perkembangan dalam aspek fisik, kognitif, sosioemosional, kreativitas, bahasa dan komunikasi yang khusus yang sesuai dengan tahapan yang sedang dilalui oleh anak tersebut. Dari berbagai definisi, peneliti menyimpulkan bahwa anak usia dini adalah anak yang berusia 0-8 tahun yang sedang dalam tahap pertumbuhan dan perkembangan, baik fisik maupun mental. Anak usia dini adalah anak yang berada pada usia 0-8 tahun. Menurut Beichler dan Snowman (Yulianti, 2010: 7), anak usia dini adalah anak yang berusia antara 3-6 tahun. Sedangkan hakikat anak usia dini (Augusta, 2012) adalah individu yang unik dimana ia memiliki pola pertumbuhan dan perkembangan dalam aspek fisik, kognitif, sosio emosional, 
kreativitas, bahasa dan komunikasi yang khusus yang sesuai dengan tahapan yang sedang dilalui oleh anak tersebut. Dari berbagai definisi, peneliti menyimpulkan bahwa anak usia dini adalah anak yang berusia 0-8 tahun yang sedang dalam tahap pertumbuhan dan perkembangan, baik fisik maupun mental.

Berdasarkan hasil observasi yang dilakukan kondisi fisik dan non fisik sumber daya tenaga penagajar di PAUD ini sangat kurang. Untuk tenaga guru hanya ada dua orang lulusan SMA. Hal ini berakibat pada banyaknya programprogram pembelajaran yang seharusnya didapat anak-anak PAUD tidak didapatkan. Dunia PAUD dan TK adalah dunia bermain. Hal ini tidak dirasakan oleh anak-anak PAUD Mekar, hal ini dikarenakan keterbatasan alat-alat permainan edukasi dan kalaupun ada akan mengalami hambatan juga terutama keterbatasan pengetahuan tentang pengunaan alat-alat permainan. Kondisi di dalam kelas juga sangat memprihatinkan, tampak banyak kursi-kursi plastik yang tiangnya sudah tidak utuh lagi, ruang kelas yang kondisinya sangat lusuh.

Mitra sangat membutuhkan tata cara penetaan secara baik, mitra juga sangat membutuhkan alat-alat permainan edukasi, cara penggunaan, game edukasi, serta nilai karater yang terkandung didalamnya. Berdasarkan permasalahan yang dihadapai mitra di atas maka tim melakukan pengabdian kepada masyarakat di tempat mitra berupa pendampingan penguatan pendidikan karakter melalui permainan edukatif.

Adapun tujuan dilakukanya pengadian kepada masayarkat di PAUD Mekar Kecamatan Noyan yang dilakukan oleh tim Dosen pendidikan Sejarah FIPPS IKIP PGRI Pontianak ini adalah: (1) memberikan bantuan kepada masyarakat melalui mitra dalam penyelenggaraan pembelajaran di lembaga PAUD Mekar Kecamatan Noyan terkait dengan konsep yang baik tentang PAUD sebagai wahana bermain sambil belajar yang menyenangkan; (2) menemukan solusi dalam pemanfaatan buku-buku bacaan, alat permainan edukasi, dan lokasi yang menyenangkan bagi anak-anak; dan (3) optimalisasi Penataan ruangan, meja dan kursi anak-anak, poster-poster edukasi, dan taman yang menyenangkan. 


\section{METODE}

Kegiatan pengabdian kepada masyarakat yang dilakukan oleh tim Dosen Program Studi Pendidikan Sejarah FIPPS IKIP-PGRI Pontianak ini berupa pendampingan penguatan pendidikan Karater melalui permainan Edukatif di PAUD Mekar Kecamatan Noyan Kabupaten Sanggau. Adapun mitra dari pengabdian ini adalah Guru dan siswa PAUD Mekar Kecamatan Noyan Kabupaten Sanggau.

Langkah-langkah yang dilakukan oleh tim dalam rangka melaksakan kegiatan ini adalah sebagai berikut: (1) Survey, kegiatan ini di rancang oleh tim pelaksana dalam rangka pendampingan dan penguatan pendidikan karakter ini di mulai dari awal semester Genap Tahun Akademik 2017/ 2018 yaitu tepatnya pada awal semester. PKM dilaksanakan di PAUD Mekar Desa Noyan Kecamatan Noyan Kabupaten Sanggau. Survey yang paling utama yakni mengenai lokasi kegiatan yang akan dituju dengan observasi langsung pada tempat yang akan dituju agar mempermudah dalam pelaksanaan kegiatan nantinya. (2) Pemantapan dan penentuan lokasi dan sasaran. Waktu kegiatan pendampingan penguatan pendidikan karakter melalui permainan edukasi untuk anak usia dini di PAUD Mekar, Kecamatan Noyan, Kabupaten Sanggau. Kegiatan dilaksankan pada bulan Januari 2018 dengan melibatkan masyarakat dan lembaga PAUD Mekar Kecamatan Noyan. Sasaran kegiatan pengabdian masyarakat ini adalah Lembaga PAUD Mekar Kecamatan Noyan, Kabupaten Sanggau; (3) Pembelian bahan permainan edukasi, Pembelian bahan edukasi ini untuk menjadikan sumber atau media belajar yang menyenangkan bagi siswa PAUD; (4) pelaksanaan pendampingan penguatan pendidikan Karakter memalui permainan Edukatif.

\section{HASIL DAN PEMBAHASAN}

Karakter suatu bangsa merupakan memiliki nilai yang sangat tinggi untuk perkembangan suatu bangsa. Karakter bangsa ini dapat ditanamkan sejak usia dini. Sebagai konsep dasar pembentukan karakter, anak memerlukan rasa aman dan nyaman, dari rasa tersebut akan menumbuhkan rasa berharga, berarti dan 
bernilai pada anak. Salah satu cara untuk menanamkan pendidikan karakter ini bisa didapatkan di sekolah melalui permainan-permaianan edukasi.

Pendidikan anak usia dini merupakan pendidikan yang sangat fundamental yang berfungsi untuk membentuk karakter anak. Masa-masa usia dini merupakan masa terbaik untuk menumbuhkan dan menanamkan karakter karena pada usia 36 tahun anak mulai menjiwai nilai-nilai yang mereka rasakan disekitar mereka. Pola penguatan pendidikan karater yang diterapkan dalam kegiatan ini mengacu kepada konsep dan pedoman penguatan pendidikan kater yang dikembangkan oleh kemndikbud sebagai berikut:

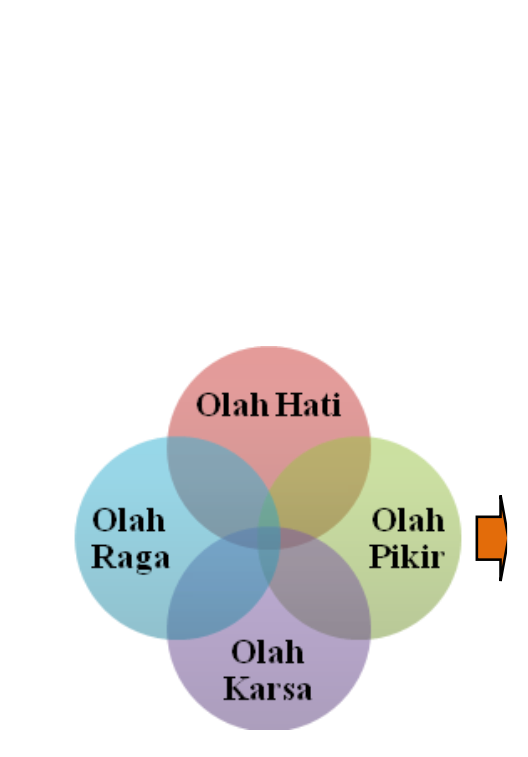

\begin{tabular}{|c|c|}
\hline Filoso & Pendidik \\
\hline $\begin{array}{l}\text { Karakter, } \\
\text { Dewantara }\end{array}$ & Hajar \\
\hline
\end{tabular}
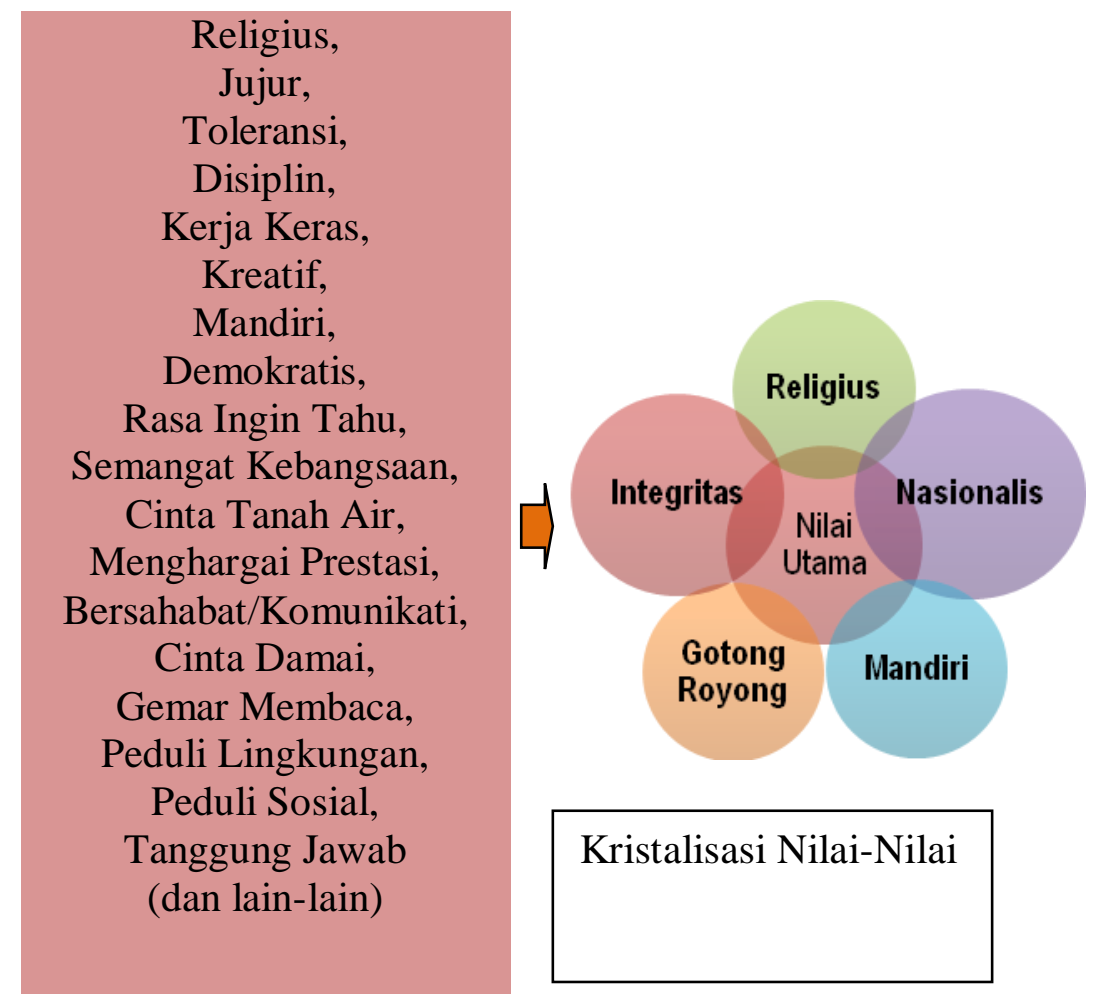

Keberhasilan pembelajaran di PAUD salah satu faktor yang mempengaruhi adalah penggunaan sumber belajar. Harus diperhatikan dalam pemilihan permainan anak, permaianan tersebut harus mampu untuk mengedukasi siswa. Prinsip dasar pendekatan pembelajaran anak di TK meliputi bermain sambil belajar dan belajar seraya bermain, pembelajaran berorientasi pada perkembangan anak, pembelajaran berorientasi pada kebutuhan anak, pembelajaran berpusat pada anak, pembelajaran menggunakan pendekatan tematik, pembelajaran pakem, 
pembelajaran mengembangkan kecakapan hidup, pembelajaran yang didukung oleh lingkungan yang kondusif, pembelajaranyang demokratis, dan pembelajaran yang bermakna. Prinsip pembelajaran ini akan mencapai hasil yang maksimal dengan memadukan berbagai metode dan teknik yang memungkinkan semua indera digunakan sesuai dengan karakteristik masing-masing sekolah (Depdiknas, 2005).

Kegiatan pengabdian kepada masyarakat di lakukan oleh tim Dosen dari Program Studi pendidikan Sejarah FIPPS IKIP-PGRI Pontianak untuk tahun 2017 di PAUD Mekar Kecamatan Noyan ini diawali dari studi awal atau peninjauan awal lokasi kegiatan. Tim mengutus salah satu anggota yaitu Yuver kusnoto M.Pd untuk melakukan koordinasi awal, dalam rangka mengumpulkan data dan pengamatan situasi atau observasi tempat pengabdian. Hal ini dilakukan dalam rangka mengumpulkan data-data awal terkait dengan permasalahan yang tengah dihadapi mitra, dan juga kebutuhan yang saat ini sedang diperlukan.

Setelah kegiatan koordinasi dilakukan tim kembali mengadakan peremuan dengan anggota dalam menyusun dan menganalisis situasi dari hasil pra observasi yang dilakukan, menyusun program-program yang akan dilaksanakan, menginventaris alat-alat permiana edukasi yang akan di beli. Menurut Suryadi (2007), bahwa manfaat mainan edukatif sebagai berikut:

1. Melatih kemampuan motorik. Stimulasi untuk motorik halus diperoleh saat menjumput mainan, meraba, memegang dengan kelima jarinya, dan sebagainya, sedangkan rangsangan motorik kasar didapat anak saat menggerakkan mainannya, melempar, mengangkat dan sebagainya.

2. Melatih konsentrasi. Mainan edukatif dirangsang untuk menggali kemampuan anak, termasuk kemampuannya dalam berkonsentrasi. Saat menyusun puzzel katakanlah anak dituntut untuk fokus padagambar atau bentuk yang ada di depannya, ia tidak berlari-larian atau melakukan aktifitas fisik lain sehingga konsentrasinya bisa lebih tergali. Tanpa konsentrasi, bisa saja hasilnya tidak memuaskan.

3. Mengembangkan konsep sebab akibat. Contohnya dengan memasukkan benda kecil ke dalam benda yang besar, anak akan memahami bahwa benda 
yang lebih kecil bisa dimuat ke dalam benda yang lebih besar. Sedangkan benda yang lebih besar tidak bisa masuk ke dalam benda yang lebih kecil. Ini adalah pemahaman konsep sebab akibat yang sangat dasar.

4. Melatih bahasa dan wawasan. Permainan edukatif sangat baik bila diikuti dengan penuturan cerita. Hal ini akan memberikan manfaat tambahan buat anak, yakni meningkatkan kemampuan bahasa juga keluasan wawasan.

5. Mengenalkan warna dan bentuk. Dari mainan edukatif, anak dapat mengenal ragam/variasi bentuk dan warna. Ada benda berbentuk kotak, segi empat, bulat, dengan berbagai warna, biru, merah, hijau dan lainnya.

Dari analisis kebutuhan mitra maka tim mengadakan alat-alat d iantaranya: kotak pensil, buku gambar, buku mewarnai, pensil, pensil warna grabel, penggraris, rautan, blok 176 pcs, mainan masak-masak, buah-buahan potong, binatang karet, satu set mainan alat dokter, alfabet, angka, papan tulis mini, wall sticker peta dunia, alat pengukur tinggi badan, alat praga perkalian, Buah mainan, alat permaian tukang, puzzle, lacing Shoe, water doole book, safari, water doole matt, miniatur traffic sign, animal finger puppet, intelligence stick, 3d blok 6 side, tagam, dan buku-buku cerita.

Menurut Badru (2007: 7-15), pemilihan alat-alat permainan edukasi yang tepat untuk anak dengan memperhatikan hal-hal sebagai berikut:

1. Alat peraga tidak berbahaya bagi anak atau merangsang agresivitas anak, seperti pedang pedangan atau pistol-pistolan.

2. Pemilihan bukan berdasarkan pilihan guru tetapi berdasarkan minat anak terhadap mainan tersebut ketika ia bermain.

3. Alat bermain sebaiknya bervariasi sehingga anak dapat bereksplorasi dengan mainannya tersebut.akan tetapi tidak terlalu banyak macamnya karena akan membingungkan anak.

4. Tingkat kesulitan sebaiknya disesuaikan dengan rentang usia anak TK, yaitu rentang 4-5 tahun untuk kelompok A dan 5-6 tahun untuk kelompok B.

5. Alat permainan tidak rapuh atau mudah rusak.

6. Tidak memilih alat permainan berdasarkan urutan usia karena ada anak yang lambat perkembangannya dari anak-anak seusianya atau sebaliknya, maka 
dasar pemilihan alat permainan lebih cenderung pada perkembangan fisik dan mental anak secara individual.

Persiapan lain adalah tim menyusun beberapa permainan atau game untuk di laksanaka pada saat kegiatan diantaranya adalah game cara berkenalan, game membagi kelompok. Mainan edukasi tersebut dipilih untuk mengasah kemampuan siswa yang disesuaikan dengan pengembangan nilai-nilai pendidikan karakter. Pemilihan mainan edukasi disesuaikan juga kontribusinya dalam memberikan pengalaman belajar. Dale's Cone of Experiance menjadi tolok ukur dalam pemilihan mainan edukasi tersebut. Adapun Dale's Cone of Experiance dapat di lihat dalam gambar 1.

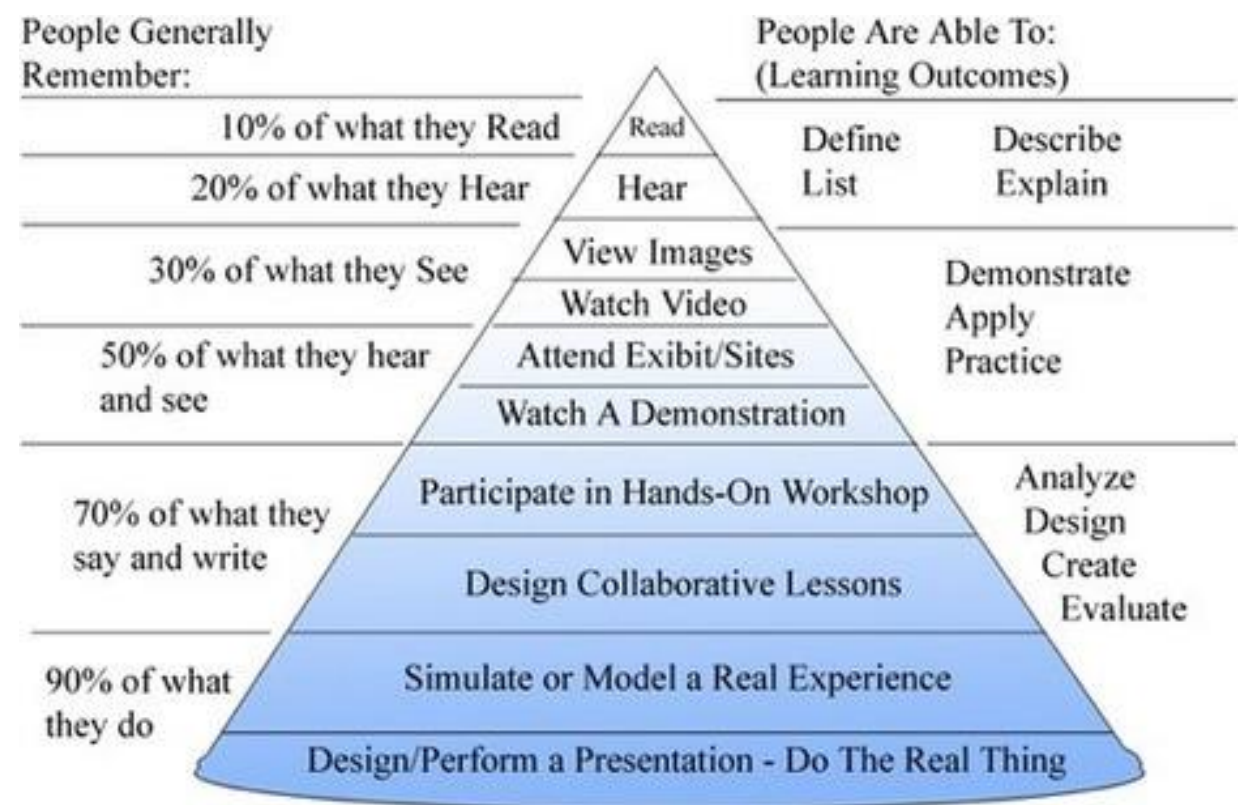

\section{Dale's Cone of Experience}

\section{Gambar 1. Dale's Cone of Experiance}

Setelah perencanaan sudah diangap matang maka tim menuju lokasi mitra, untuk melaksanakan kegiatan sesuai dengan rencana yang sudah dipersiapkan sebelumnya. Pertama memperkenalkan jenis-jenis atau alat-alat permainan yang sudah disiapkan oleh tim, menerangkan cara-cara menggunakan, dan menyampaikan kegunaan atau nilai-nilai karater yang terkandung pada setap alat 
permainan dan game yang digunakan. Peserta terlihat antusias dan menyambut setiap kegiatan-kegiatan yang dilakukan oleh tim.

Alat permainan pertukangan mendorong siswa untuk bekerjasama dengan temannya. Selain mengenalkan jenis-jenis alat pertukangan, guru menginstruksikan untuk bermain peran sebagai tukang bangunan dan belajar menggunakan alat pertukangan, mereka bekerja sama sebagai tukang untuk menyelesaikan perkerjaan pertukangan. Kegiatan belajar mengajarkan siswa untuk saling bergotong royong dan kerja keras dalam menyelesaikan tugas yang dioberikan oleh guru. Mencobakan anak-anak untuk bermaian sebagai tukang dapat memberikan pengalaman belajar $90 \%$ seperti dalam Dale's Cone of Experience dari Edgard Dale.

Buku cerita merupakan salah satu jendela ilmu. Buku-buku cerita yang diberikan ke PAUD Mekar terdiri dari beberapa macam, diantaranya buku cerita rakyat, buku pengenalan hewan, buku cerita toleransi. Beberapa buku yang diberikan selain mengenalkan warna anak-anak juga dapat mengambil nilai-nilai yang terkandung dalam buku tersebut. Sesuai dengan Dale's Cone of Experiance bahwa manusia memiliki kemampuan belajar 30\% dari melihat gambar. Bukubuku cerita bergambar membentuk nilai-nilai jujur, toleransi, rasa ingin tahu, bersahabat/komunikatif, gemar membaca, peduli lingkungan.

Mainan binatang karet terdiri dari beberapa miniatur hewan. Miniatur hewan ini sangat membantu ketika anak membaca buku cerita bergambar mereka bisa menyentuh miniatur hewan-hewan tersebut, sehingga dapat memberikan pengalaman belajar yang lebih kepada anak. Dipadukan dengan animal finger puppet anak juga dapat bercerita dengan memainkan peran. Disini akan memunculkan daya imajinasi dan kreatifitas anak. Dengan pendampingan dari guru anak-anak dapat menciptakan sebuah cerita yang menarik dan memberikan kepada mereka nilai-nilai kehidupan.

Mainan masak-masakan dan miniatur buah dan sayuran dapat membantu anak dalam mengimajinasikan sebuah menu makanan yang dapat mereka masak bersama-sama. Selain mendorong kreatifitas anak, juga menekankan gotong royong dalam membuat makanan. 
Pada saat yang bersamaan sebagian tim melaksanakan pemasangan alat-alat edukasi lainnya di rungan kelas yang lain seperti memasang alat pengukur tinggi badan, wall sticker peta dunia dan beberapa alat yang lain. Sekaligus menerangkan kegunaan dan cara memakainya.

Setelah kegiatan bersama guru dan siswa selesai dilaksanakan. selanjutnya adalah memberikan materi penguatan kepada guru yang mengajar di Paud Mekar agar tetap bertahan mengajar disana. Hal ini dilakukan tim karena berdasarkan analisis situasi sebelumnya ditemukan kurangnya motivasi dari guru untuk mengajar disana dikarenakan beberapa permasalahan dianataranya, fasilitas yang sangat kurang, pendapatan yang tidak memadai, dan jumlah tenaga pengajar yang sangat terbatas yakni hanya dua orang. Setelah dilakukan pendampingan dan penguatan yang meyakinkan guru merasa termotivasi kembali untuk tetap mengajar di sana. Hal ini perlu dilakukan karena guru menjadi panutan anak dalam belajar, dan tugas guru membimbing anak untuk membentuk karakter yang baik.

Kegiatan akhir dari pengabdian yang dilakukan oleh tim adalah evaluasi. Berdasarkan hasil evaluasi yang dilakukan terdapat beberapa kendala atau kekurangan pada saat kegiatan ini dilaksanakan diantaranya adalah lokasi tergolong jauh. Kurangnya sarana dan prasarana belajar.

\section{SIMPULAN}

Berdasarkan uraian hasil dan pembahasan dapat disimpulkan bahwa penguatan pendidikan karakter untuk anak PAUD dapat dilakukan dengan menggunakan permainan edukasi. Ketika permainana itu digunakan dengan tepat dan dalam pengawasan guru maupun orang tua dapat ditanamkan nilai-nilai pendidikan karakter religius, jujur, toleransi, disiplin, kerja keras, kreatif, mandiri, demokratis, rasa ingin tahu, semangat kebangsaan, cinta tanah air, menghargai prestasi, bersahabat/komunikatif, cinta damai, gemar membaca dan peduli lingkungan. 


\section{UCAPAN TERIMA KASIH}

Pengabdian pada masyarakat dengan tema "Pendampingan Penguatan Pendidikan Karakter Melalui Permainan Edukatif di PAUD Mekar Kecamatan Noyan" tidak dapat terwujud tanpa bantuan dari berbagai pihak. Maka dari itu tim ingin mengucapkan terima kasih kepada IKIP PGRI Pontianak yang telah memberikan bantuan dana pengabdian, bapak ibu guru di PAUD Mekar Noyan yang telah memberikan kesempatan kepada tim untuk melaksanakan kegiatan pengabdian.

\section{DAFTAR PUSTAKA}

Augusta. 2012. Pengertian Anak Usia Dini. Dari http://infoini.com/ Pengertian Anak Usia Dini.

Depdiknas. 2005. Pedoman Pembelajaran di Taman Kanak-Kanak. Jakarta: Direktorat Pembinaan Taman Kanak-Kanak Sekolah Dasar.

E. Dale, Audiovisual Methods in Teaching, 1969, NY: Dryden Press. Prenada Media Group.

Sagala, S. 2006. Konsep dan Makna Pembelajaran. Bandung: Alfabeta.

Suryadi. 2007. Cara Efektif Memaham Perilaku Anak Usia Dini. Jakarta: EDSA Mahkota.

Yulianti, D. 2010. Bermain Sambil Belajar Sains di Taman Kanak-Kanak. Jakarta: PT Indeks.

Badru, Z., dkk. 2007. Media dan Sumber Belajar TK. Jakarta: Universitas Terbuka. 